\title{
Analysis of The Implementation of Smart Governance through Twitter in Local Governments in Indonesia
}

\author{
Iman Surya'1), Niken Nurmiyati1)*, Suranto²) \& Nur Hasanah'1) \\ 1)Government Science, Social and Political Science Faculty, Universitas Mulawarman, \\ Indonesia \\ 2)Magister of Government Science, Social and Political Science Faculty, \\ Universitas Muhammadiyah Yogyakarta, Indonesia
}

Received: July 26, 2021; Reviewed: July 26, 2021; Accepted: September 05, 2012

*Corresponding Email: niken96unmul@gmail.com

\begin{abstract}
The research entitled "Analysis of the Implementation of Smart Governance through Twitter in Local Governments in Indonesia" is a study that focuses on the analysis of branding, criticality, participation, and transparency. This study aims to find out about the use of Twitter in Government. This research is qualitative research using artificial-intelligent software NVivo 12 Plus. The results showed that the function of branding in the health sector in Central Java dominated, followed by DKI Jakarta, Bandung City, and Surabaya City. The superior crisis function is the health crisis with the highest position, namely Central Java, Bandung City, DKI Jakarta, and Surabaya City. The participation function superior in terms of public engagement is DKI Jakarta; the participation function in the superior collaboration field is the City of Surabaya, Bandung City, and Central Java. The function of transparency in terms of superior service is DKI Jakarta, Surabaya City, Central Java, and Bandung City.
\end{abstract}

Keywords: Smart Governance; Twitter; Local Governments.

How to Cite: Surya, I., Nurmiyati, N., Suranto., Hasanah, N. (2021). Analysis of The Implementation of Smart Governance through Twitter in Local Governments in Indonesia. Jurnal Administrasi Publik (Public Administration Journal). 11 (2): 169-184 


\section{INTRODUCTION}

The internet and technological convergence and normalization have characterized the development of Information and Communication Technology (ICT) (Castelnovo et al., 2016). Smart cities have been implemented in large numbers in response to technological advancements. In the present era, a smart city makes extensive use of ICT, with numerous benefits and applications (Almeida et al., 2018).

This is evidenced by the existence of various cities worldwide that see the possibility of overcoming challenges by adopting the concept of a 'smart city in urban planning life (Allwinkle \& Cruickshank, 2011; Ruhlandt, 2018). One of the main goals of smart cities is to improve the quality of life in cities, such as addressing the problem of increasing urbanization and focusing on well-being (Pereira et al., 2018).

A smart city has six dimensions: smart living, smart environment, smart economy, smart people, smart mobility, and Smart Governance. This research will discuss further smart Governance. Smart
Governance is understood as intelligent technology in processing information and making decisions (Pereira et al., 2018). Smart Government is present as one of the important features in Government, one of which is by using Twitter.

The presence of Twitter allows the Government to use Twitter in various new modes of interaction that can be used as a means of interacting between the Government and users (Medaglia \& Zhu, 2017). Twitter plays an important role in modern society, just as in the last few decades, governments have adopted Twitter as a communication method that engages citizens (Guillamón, Ríos, Gesuele, \& Metallo, 2016).

According to Wearesocial Hootsuite data provided in January 2021, Indonesia's number of Twitter users hit 170 million, or 61.8 percent of the overall population. This data is up $6.3 \%$ from the previous survey. Moving on from Twitter, the number of gadget users is no less competitive, with a total of 168 million people who access Twitter via mobile phones. It can be seen in the picture:

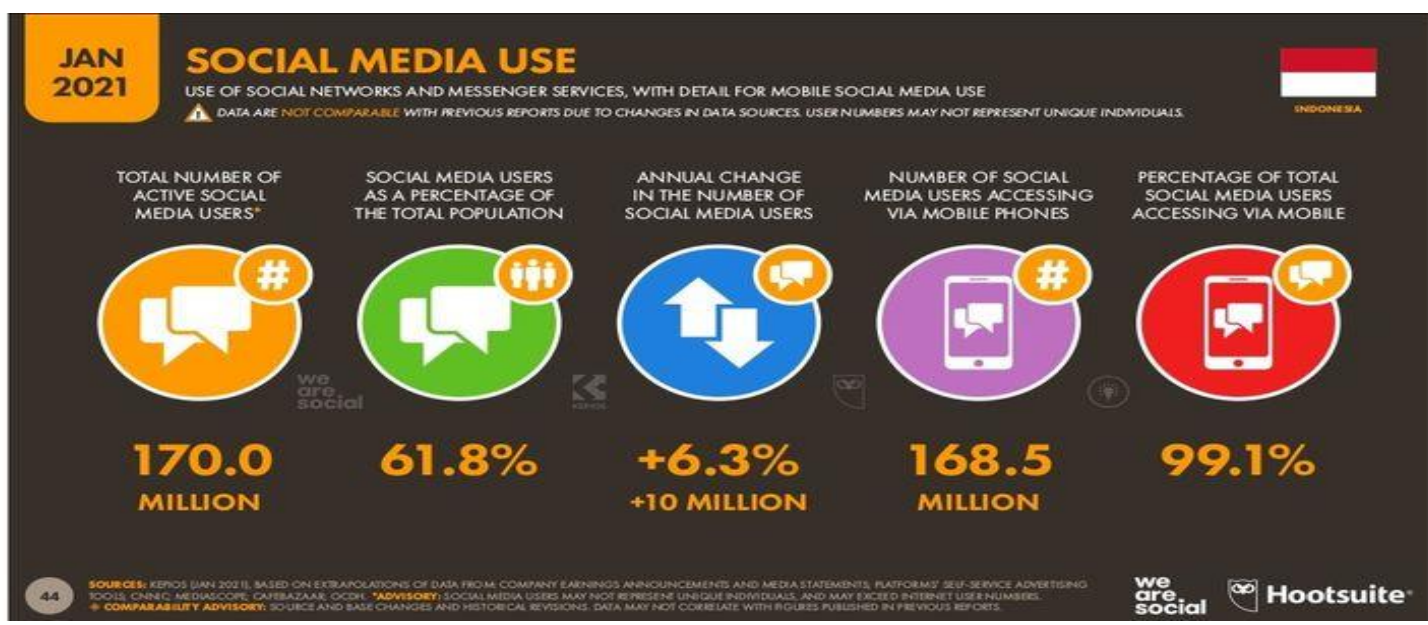

Figure 1: Twitter Users in Indonesia Version We Are Social

Source: We Are Social, Jan 2021

According to Figure 1, the Indonesian for work, business, and communication. population can utilize their mobile phones This phenomenon is widespread and 
widespread in quantity, affecting everyone from the young to the old. Because mobile phones are so widespread, it is not uncommon for every phone to be equipped with specific functions, such as the Twitter feature as a form of communication.

The results of research by Nurmandi et al. (2018) show that the evolution of the use of Twitter in Government consists of four stages, namely promotion (the presence of Twitter), transformation (transformation of media that has a social impact), engagement (Twitter that affects government stakeholders) and impact (interaction). Twitter).

About smart Governance, Twitter offers governments a new approach to create transparency and accountability, increase the opportunities for citizens to participate and collaborate in decisionmaking, or enable the improvement of public services. (Guillamón et al., 2016).

Local governments use Twitter applications in various ways to engage citizens in project management policies and activities (Merwin et al., 2016). As a social network and micro-blogging tool that can use to send instant messages to citizens to announce special events, Twitter takes advantage of the information delivery provided. It allows local politicians to examine how an event or event can be perceived and reach users or the public (Bonson et al., 2013).

This study will analyze active Twitter accounts in local governments in Indonesia, such as Bandung, the City of Surabaya, the Government of DKI Jakarta, and Central Java. The four regions are areas that actively use Twitter in Government; these areas also implement smart cities in the Government.

The coverage of cities and provinces is certainly very different; this is an interesting phenomenon to study. In general, this paper will discuss the branding function, crisis function, participation function, and transparency function,

Based on this background, the authors feel the need to research the use of Twitter in Government, especially in Bandung City, Surabaya City, DKI Jakarta Province, and Central Java Province. These areas are active users of social media in Government to communicate and share information with their citizens.

This study uses the Smart City theory. A smart city is a concept that uses information as a basis to improve comfort, facilitate mobility, increase efficiency, save energy, improve air and water quality, identify problems and fix them quickly, recover quickly from disasters, collect data to make better decisions. , deploy resources effectively, and share data to enable crosssector collaboration (Nam \& Pardo, 2011). Smart cities are sustainable, bringing together economic, social, and environmental goals (Thuzar, 2011).

Smart Governance is generally defined as the ability to use digital technology and intelligent actions to process information and make decisions (Scholl \& Alawadhi, 2016; Pereira et al., 2018). (1) smart city governance, (2) smart decision making, (3) smart administration, and (4) smart urban collaboration are the four ideal-typical conceptualizations of smart city governance identified by Meijer and Bolvar (2016).

Previous research in other regions, such as Yogyakarta, has found that the use of Twitter in Yogyakarta is deemed more responsive in responding to community desires and questions (Anggreani et al., 2020). Twitter is also thought to have been successfully used in Yogyakarta to communicate with the Community.

\section{RESEARCH METHODS}

This is a qualitative study that uses the NVIVO 12 Plus data analysis software from Artificial Intelligence. NVivo is a Qualitative Data Analysis (QDA) program developed by 
Qualitative Solution and Research (QSR) International. It has several benefits and can considerably increase the quality of research, resulting in more accurate data and a more straightforward procedure. (AlYahmady \& Al Abri, 2013).

The data analyzed relates to the implementation of smart cities through twitter in local governments in Indonesia, especially in Bandung, the city of Surabaya, DKI Jakarta, and Central Java.

\section{RESULT AND DISCUSSION}

\section{Analysis of Twitter Functions in Local} Governments in Indonesia

Branding Function. Branding is a process to make a city have its own distinct and unique identity that makes it different from other cities (Lestari, 2016). Branding is also used as a promotion of the city to make it more attractive. The personal identity of a city aims or identifies the purpose of city branding, communication between parties (Government, Community, and private sector), aspects (strategy and prospects) introducing the city. The process of introducing the city is always related to randing. Implementation to ensure what kind of communication program a city uses to be integrated and consistent in conveying messages.
One of the things that can use is to use city branding. City branding is a strategic way to provide information about a city or area to the general public, whether investors, tourists, the wider community, and others. (Raharjo, 2015). The purpose of each city in branding its region or province, of course, has a different way and has different goals. The branding of cities and provinces analyzed is Bandung City, Surabaya City, DKI Jakarta, and Central Java. The form of branding for the four regions is seen from several aspects, including health, tourism, education, achievement, and transportation. Can be seen in Figure 2.

Based on Figure 2, we can see that health branding occupies the highest position in the City of Bandung, DKI Jakarta, and Central Java. Meanwhile, the city of Surabaya has the highest educational branding, with a percentage of $39.39 \%$. In health branding, we can see that the four regions show quite high numbers. When the Covid-19 pandemic entered Indonesia, it often discussed health issues on Twitter social media accounts. So that tweets about health often appear, such as an appeal not to leave the house and always obey health protocols. More clearly can be seen in Figure 3.

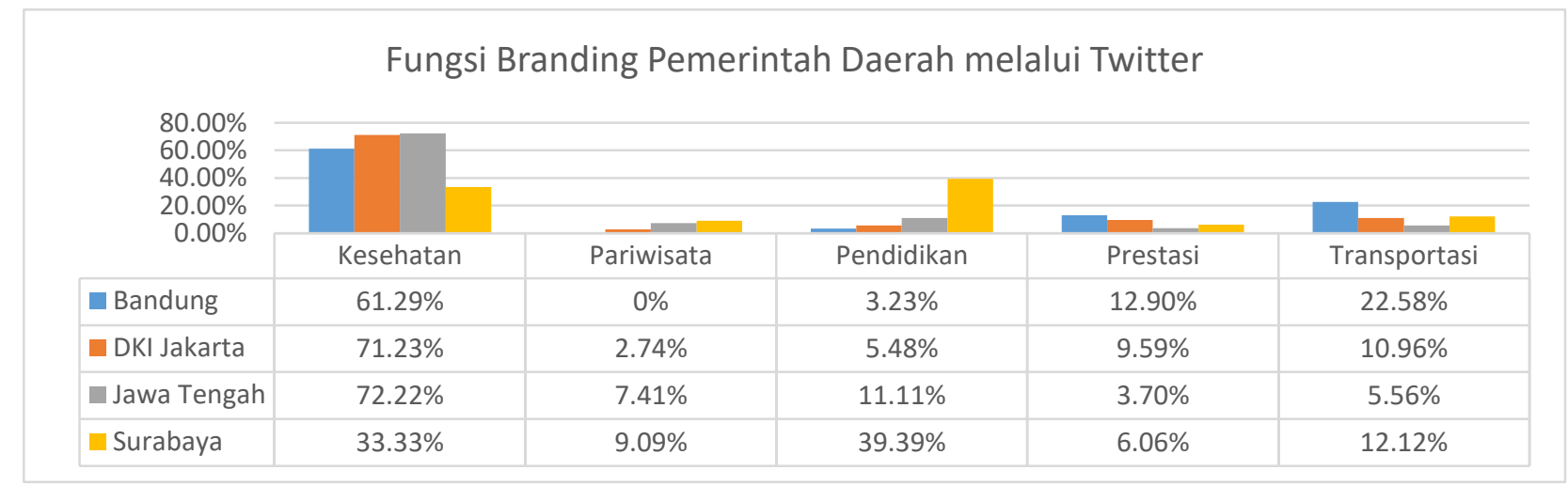

Figure 2: Branding Function

Source: Edited by the author using NVivo 12 Plus, 2021 


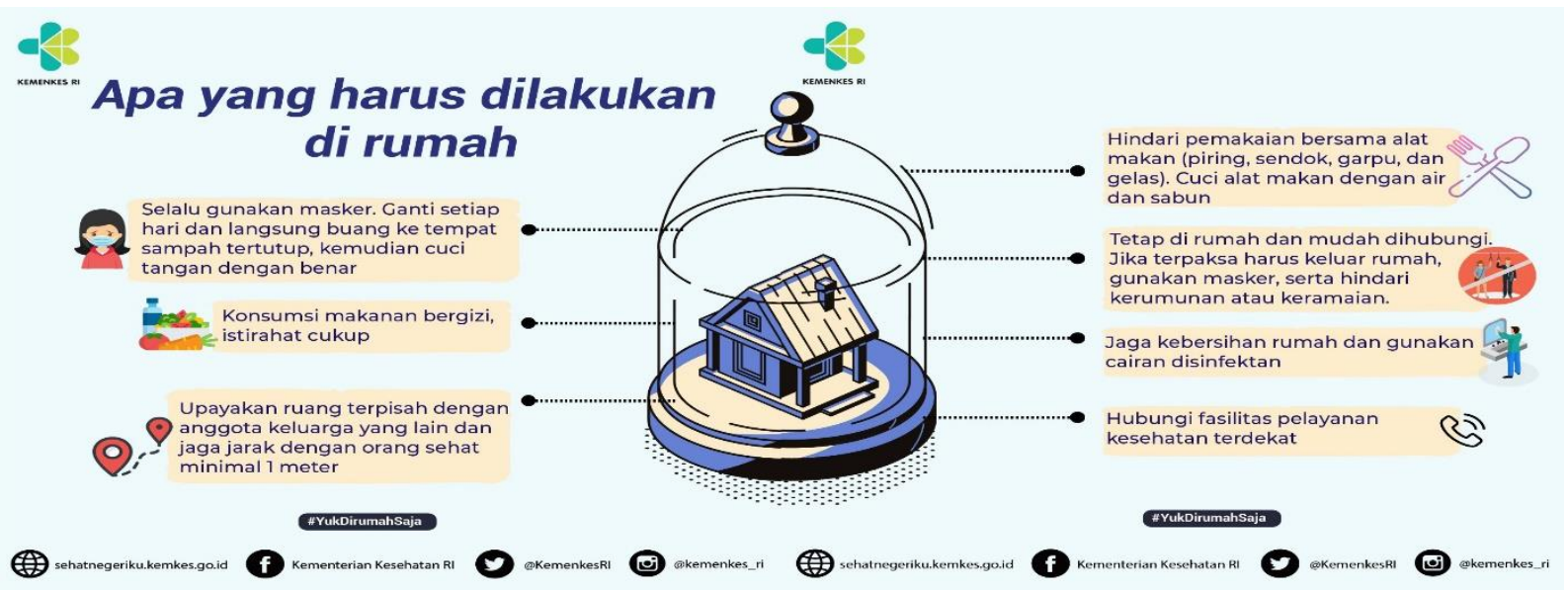

Figure 3: Health Protocol Drawing Source: https://stoppneumonia.id/protokol-kesehatan-covid-19/

Figure 3 shows that when undertaking activities outside the home, all regions in Indonesia are needed to follow health rules. Of course, the epidemic does not prevent people from going about their daily lives. Things are a little different now; according to the information gathered, the City of Surabaya remained active in education during the pandemic, even if it was just online. Tri Risma Harini, the mayor of Surabaya, is also involved in online education.

Crisis Function. The crisis function is a function that refers to a state of disaster, both natural and non-natural disasters. In this crisis indicator, there are three variables: disaster, health, and air pollution-disasters related to natural disasters such as floods, earthquakes, tsunamis, landslides, etc. Health is included in the realm of non-natural disasters such as the Covid-19 pandemic. Air pollution refers to the state of air pollution due to factory fumes and vehicle pollution.

The regional government crises analyzed are Bandung City, Surabaya City, DKI Jakarta, and Central Java. Can describe it in Figure 4.

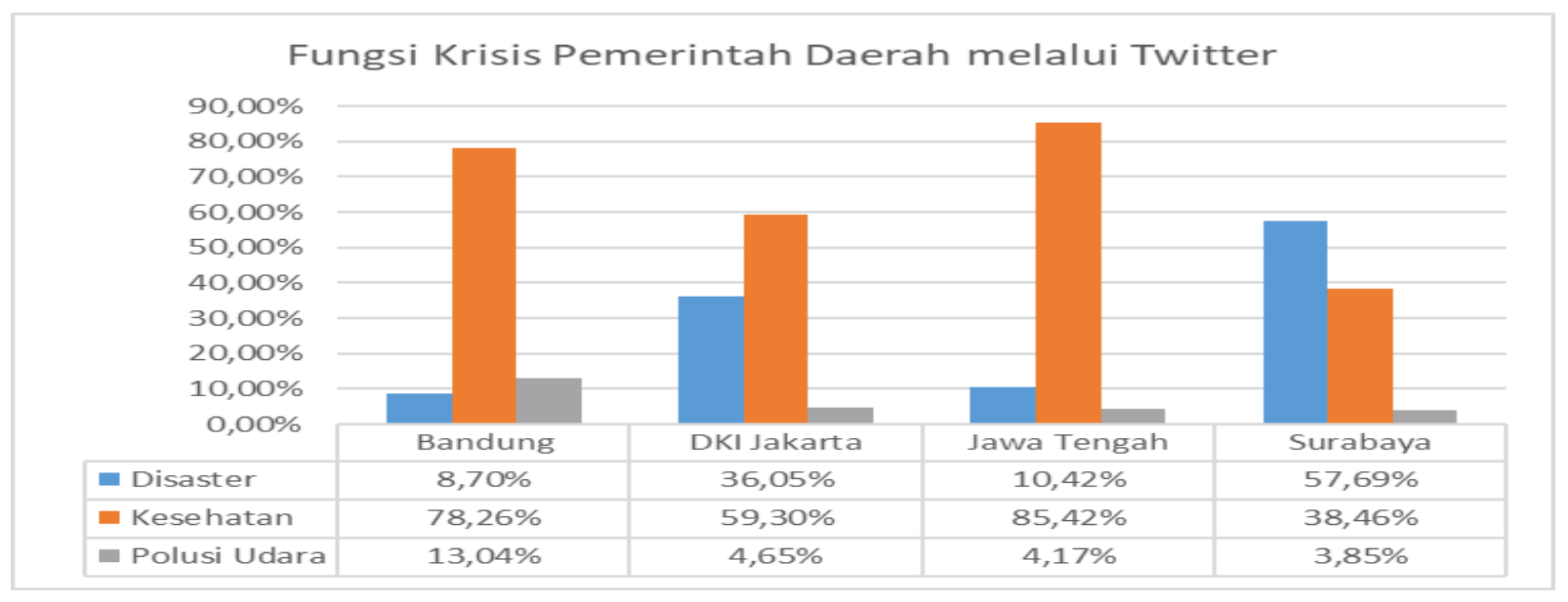

Figure 4: Crisis Function

Source: Edited by the author using NVivo 12 Plus, 2021 
The data in Figure 4 shows that in the crisis function, non-natural disasters in the health sector still occupy the highest position in Bandung City, DKI Jakarta Province, Central Java Province, and Surabaya City.

\section{Participation}

Function. Participation can be linked to physical or non-physical development processes or programs (Bakarbessy, 2020). Participation includes actions or actions taken by a person or group of people to be actively involved in an action. Participation has a significant role in the government process, both political and public participation related to service and policymaking.

Participation in the participation of the Community in the political and
Government processes. Participation is closely related to community activity in responding to and responding to a problem or phenomenon. Participation has a very high position in democracy, especially in the relationship between the Community and the Government. Participation is considered to be a bridge between interests that the Government must accommodate.

The conditions for participating in the analyzed cities and provinces were the City of Bandung, the City of Surabaya, DKI Jakarta, and Central Java. The forms of participation in the four regions are seen from several aspects, including collaboration, network, politics, and public engagement. This can be seen in Figure 5.

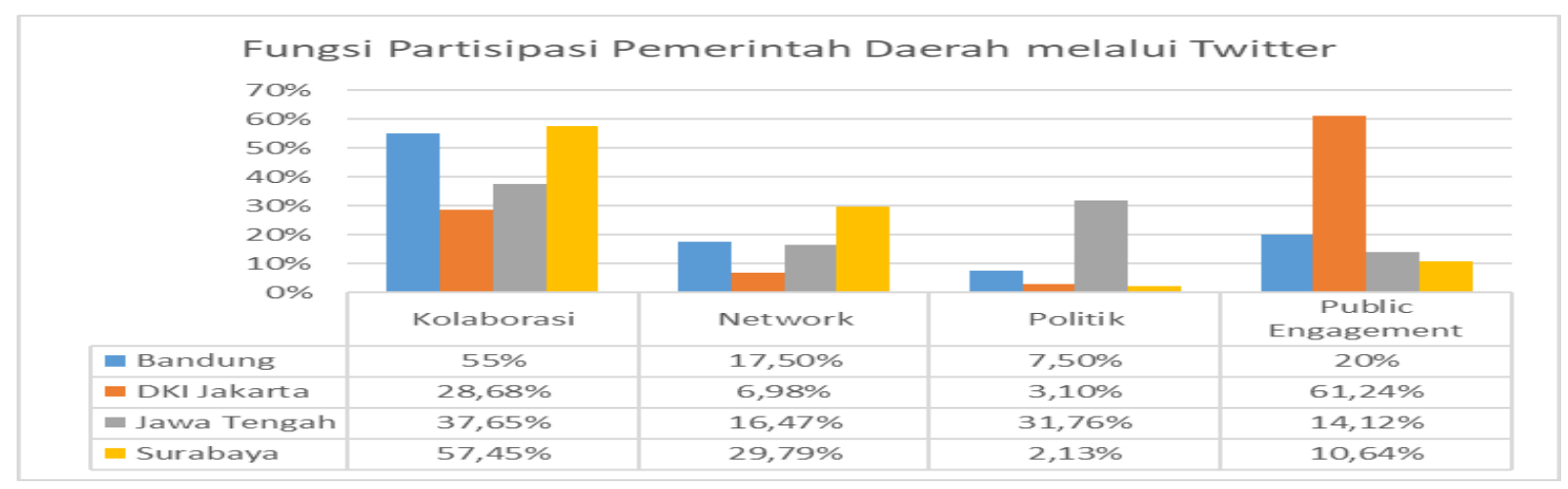

Figure 5: Participation Function

Source: Edited by the author using NVivo 12 Plus, 2021

Figure 5 shows four aspects, with the political aspect accounting for the smallest share among the others. This is owing to the growth in health concerns around the Covid-19 outbreak, which has drawn widespread attention. Among the other regions, Central Java has the greatest rate of political participation. Figure 6 depicts one of the calls for the election to be held during a pandemic. 


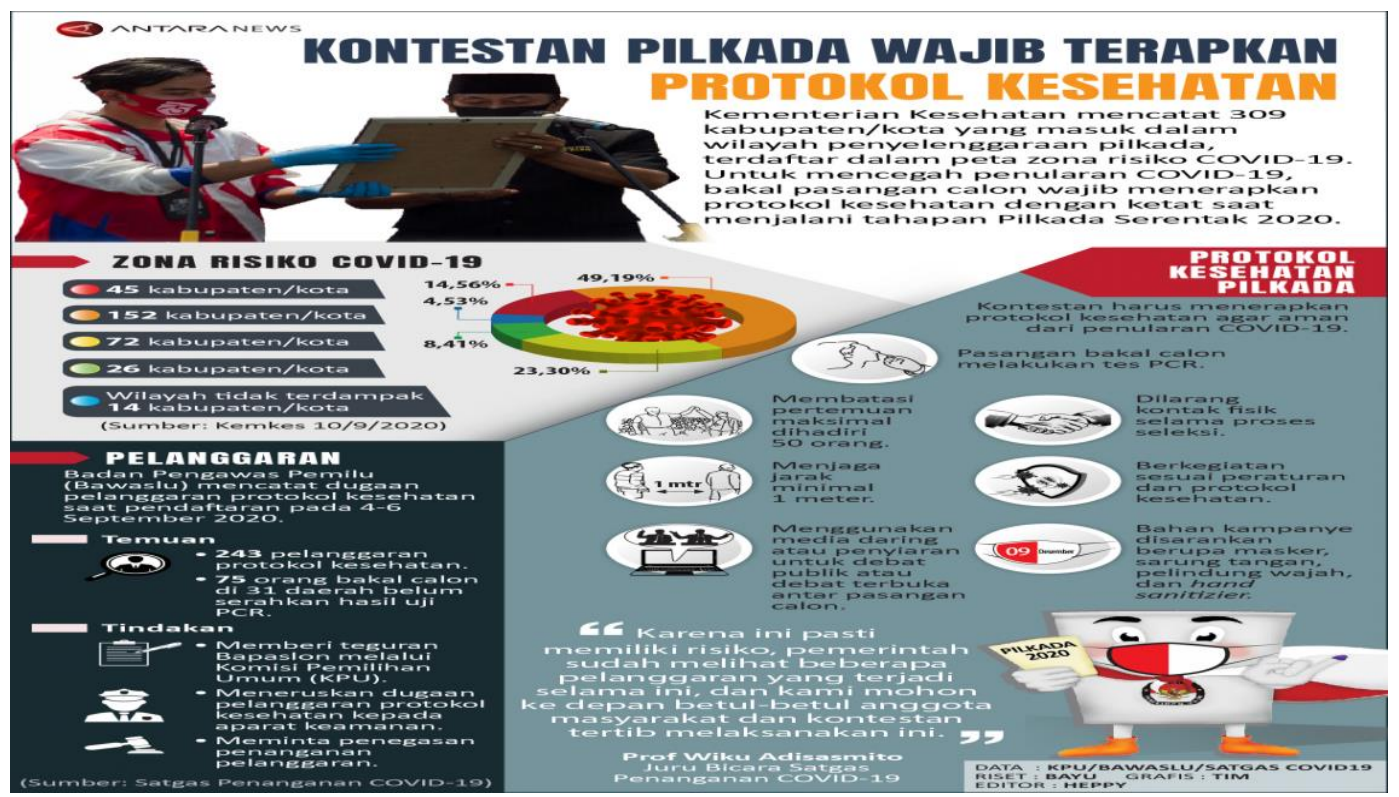

Figure 6: Election contestation according to Health Protocol Source: https://www.antaranews.com/infografik

\section{Transparency}

Transparency Government's efforts to provide information related to social, political, economic, and all fields that involve the Community in providing availability, trust, and accessibility of information among stakeholders (Muis, 2020). Transparency is also interpreted as disclosing information
Function. to the public on what activities the Government has carried out.

The transparency of local governments in Bandung City, Surabaya City, DKI Jakarta, and Central Java is being examined. Budgets, service innovations, policies, and services all play a role in determining the level of transparency in the four areas. Figure 7 illustrates this.

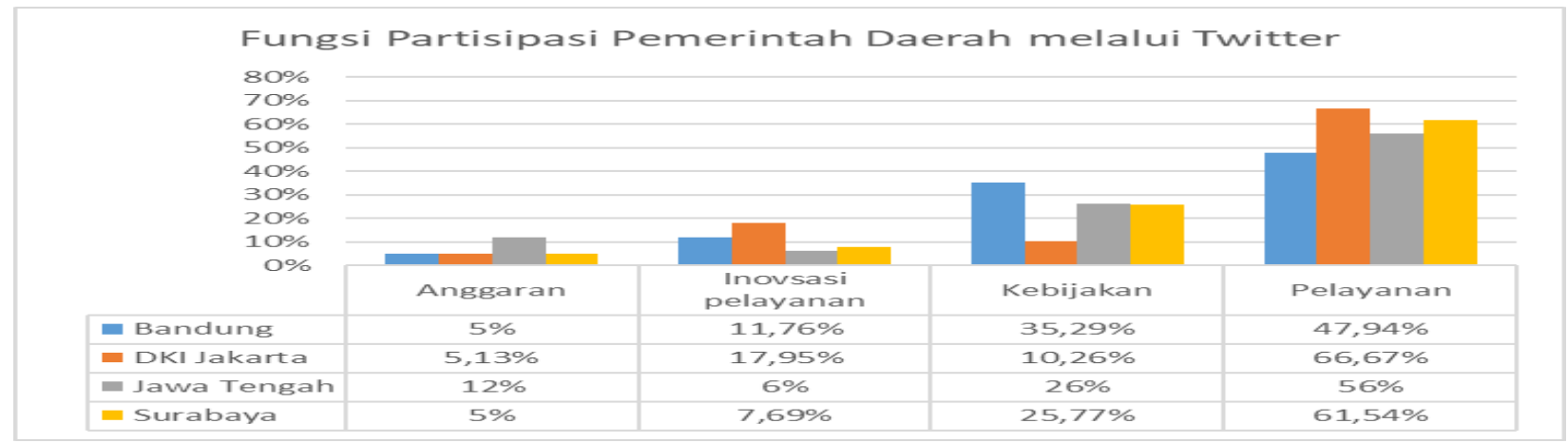

Figure 7: Transparency Function

Source: Processed by the author using NVivo 12 Plus, 2021

Figure 7 discusses budget province with the most informative transparency; Central Java is better than national KIP in 2020, beating DKI Jakarta other regions with $5.13 \%$. This is in line and West Java. The data in Figure 8 support with the fact that Central Java is the this. 

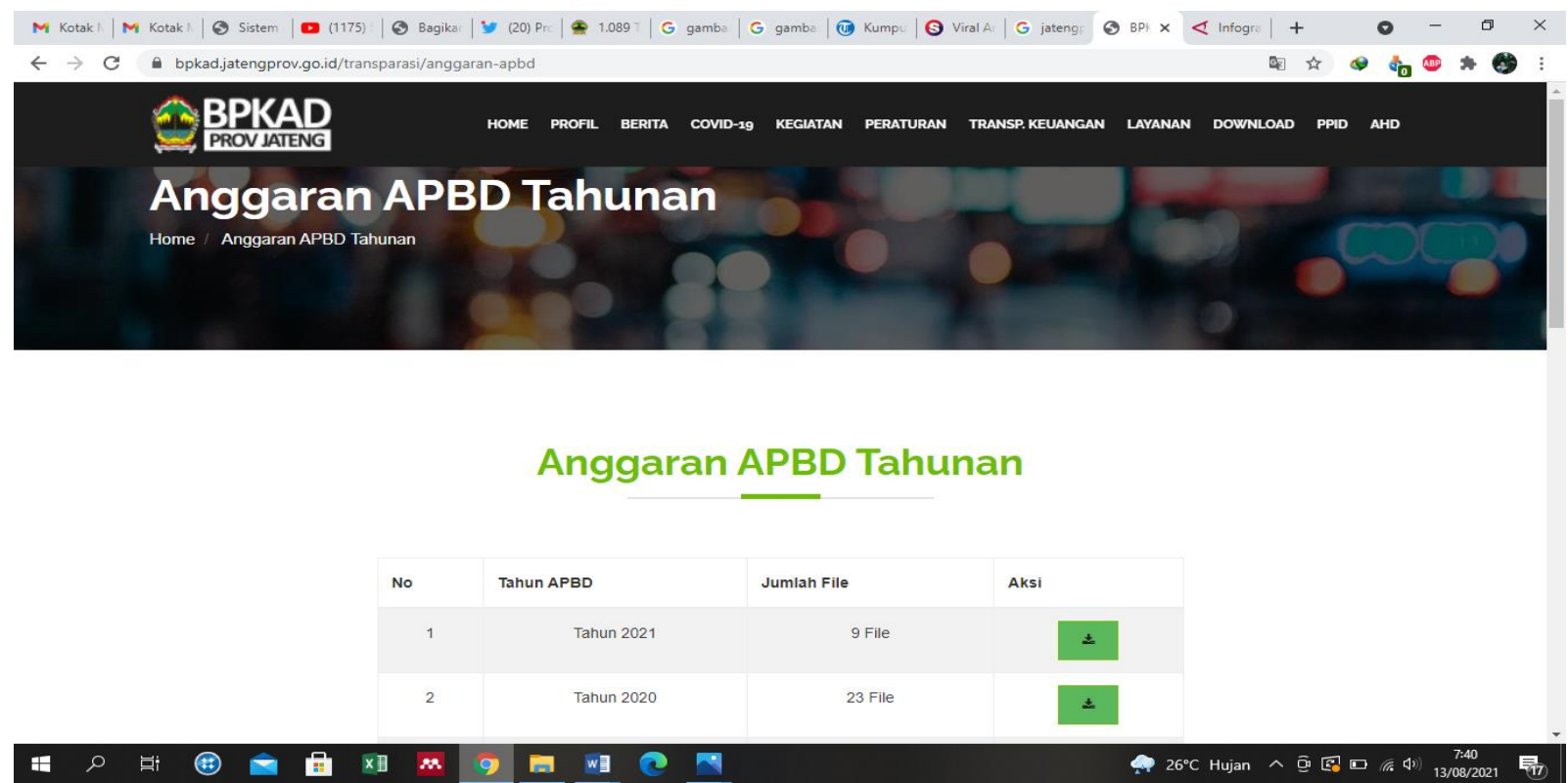

Figure 8: Example of Transparency

Source: https://bpkad.jatengprov.go.id/transparasi/anggaran-apbd

Figure 8 shows that the transparency of Central Java Province, which ranks the highest, is supported by the data. Another category, namely service innovation, DKI Jakarta, is superior to other regions with $17.95 \%$. This is because the DKI Jakarta Provincial Government received the Top 45 Public Service Innovation Award from the Ministry of Administrative and Bureaucratic Reform.

The city of Bandung achieved another transparency function in terms of policy transparency with a percentage of $35.29 \%$. The policy in question is written on the @humasbdg Twitter account that many discussions related to the covid pandemic do not make physical contact, open and close road access, and provide administrative sanctions for residents who violate.

\section{Hashtag on Twitter account @HumasBdg}

The information conveyed by the Twitter accounts of each local Government in Indonesia can be seen from the very diverse use of hashtags used. The hashtags used by the City of Bandung in the @HumasBdg twitter account consist of
\#Bandung \#Bandungnuurang209, Citymenresponding,

Citylawancovid19, \#Bandung \#bersamakitatangguh, \#Bandung City, \#cpns2019, \#dirumahaja, and \#Bandungkota preventcovid19. More clearly can be seen in Figure 9. Figure 9 above shows that the hashtag used by the City of Bandung with the highest percentage is \#Bandunglawancovid19 City with the highest score, followed by \#Bandungnuuran209 City and \#Bandung CitymenAnswer. Can analyze that the conversation raised by the @HumasBdg Twitter account leads to one theme, namely \#Bandunglawancovid19, with a number approaching 140 hashtags on Twitter. The hashtag \#Bandunglawancovid19 has become a high focus on health.

\section{Hashtag on Twitter account @DKIJakarta}

The hashtags used by DKI Jakarta in the @DKIJakarta twitter account consist of \#jagajakarta, \#covid19, \#psbbtransisi, \#dkijakarta, \#jagajarak, \#wearmasker, \#jakartasamrtcity, and \#transjakarta. This can be seen in Figure 9. 
Iman Surya, Niken Nurmiyati, Suranto \& Nur Hasanah, Analysis of The Implementation of Smart

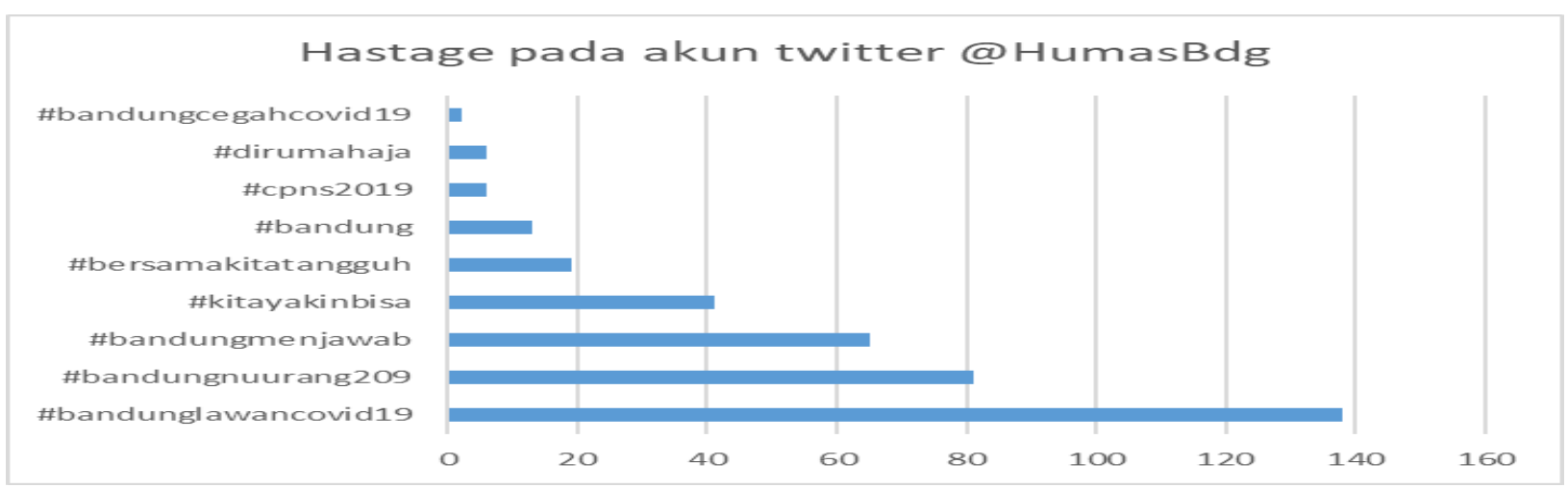

Figure 9: Hashtags frequently used by the @HumasBdg akun account Source: Edited by the author using NVivo 12 Plus, 2021

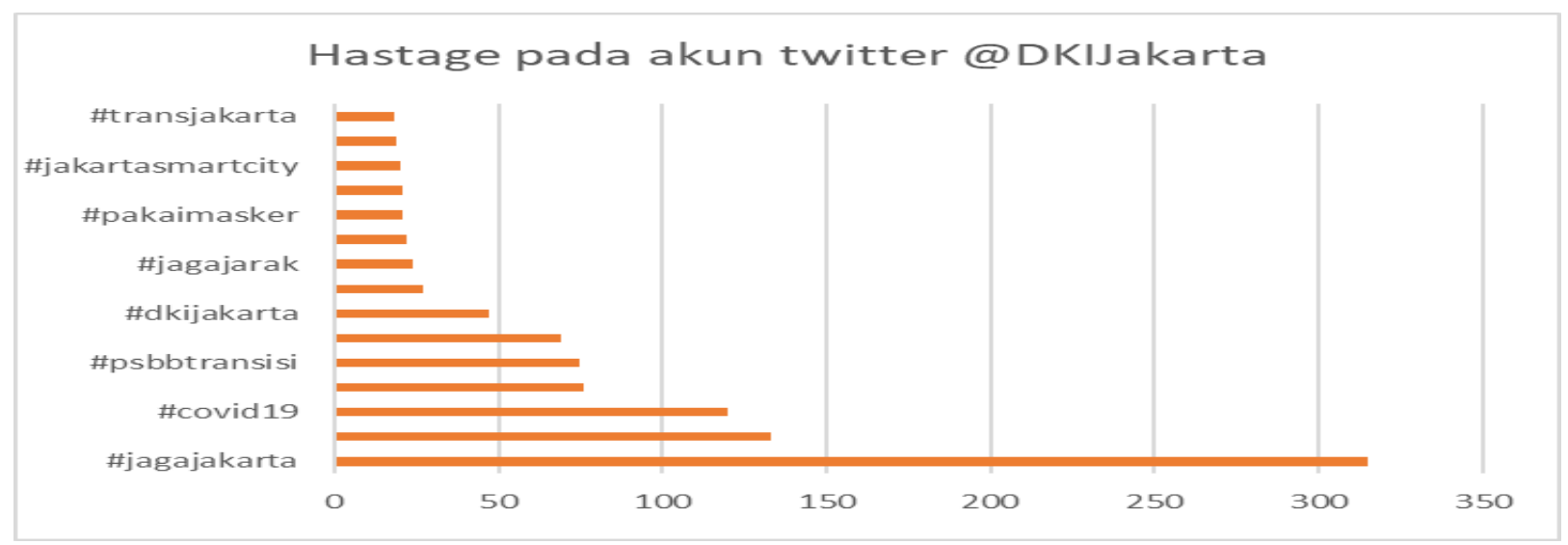

Figure 10: Hashtags that are often used by the @DKIJakarta account Source: Edited by the author using NVivo 12 Plus, 2021

Figure 10 shows the hashtags used by DKI Jakarta, with the highest percentage being \#jagajakarta with the highest value exceeding 300 tweets, followed by \#covid19 and \#psbbtransisi. Can analyze that the discussion raised by the @DKIJakarta Twitter account leads to one theme, namely about \#jagajakarta with a number exceeding 300 tweets on Twitter. The hashtag \#jagajakarta has become a focus related to health. This means DKI Jakarta is focused on inviting the public to protect Jakarta during the pandemic. One of the things that often becomes a public discussion in DKI Jakarta is about the Transitional PSBB. The next hashtag also wrote a lot related to the Covid-19 pandemic.
Apart from health, things that have also become hashtags are \#jakartasmartcity and \#transjakarta. This means that DKI Jakarta is also focused on providing hashtags about smart city branding and transportation. We know that DKI Jakarta is famous for having MRT, BRT, and LRT innovations in the transportation sector. If examined further, DKI Jakarta's hashtag is much higher. This indicates that DKI Jakarta is very diverse in terms of intensive discussion in the public sphere in the social media world.

\section{Hashtag on Twitter account @provjateng}

The hashtags used by Central Java in the @provjateng twitter account consist of \#jatenggayeng, \#bersamalawancorona, 
\#jatengpedulisesama, \#dirumahaja, \#wearmasker and \#covid19. This can be \#jogotonggo, \#jateng70, \#virtualevent, seen in Figure 11.

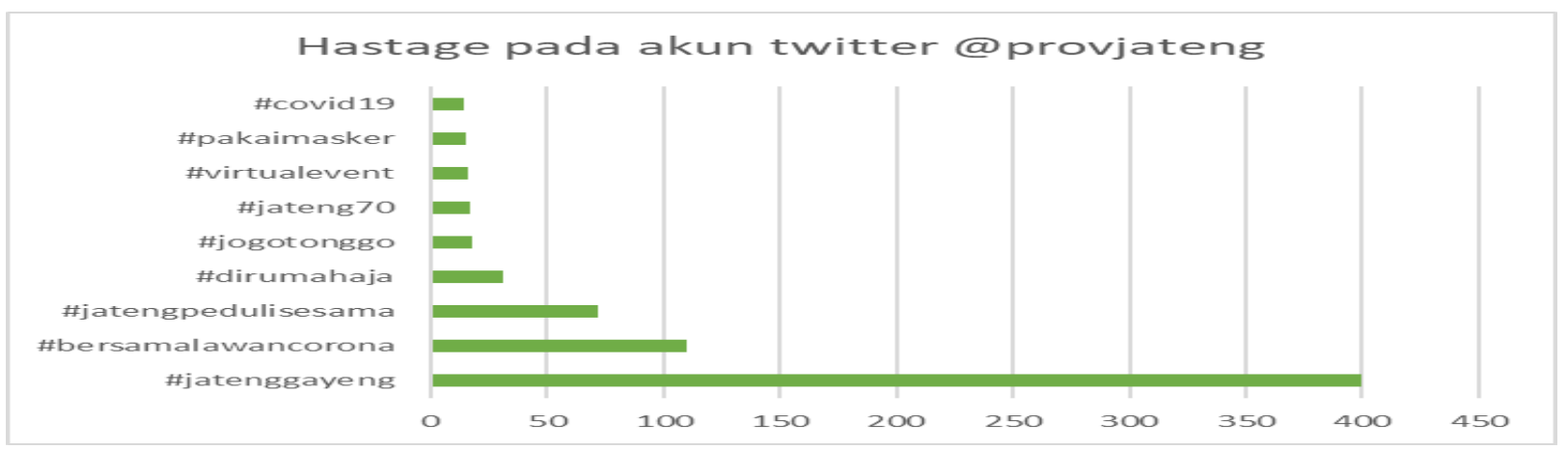

Figure 11: Hashtags that are often used by the @provjateng account Source: Edited by the author using NVivo 12 Plus, 2021

Figure 11 shows the hashtags used by Central Java with the highest percentage of \#jatenggayeng with the highest value of 400 tweets, followed by \#bersamalawancorona and \#jatengpedulisesama. Jateng Gaeng is a branding of the province of Central Java under the leadership of Ganjar Pranowo. Central Java Gayeng means passionate, brave, tough, honest, friendly, encouraging, harmonious, and warm. Central Java Gayeng was launched to promote and market various potentials and products of the province of Central Java.

Branding carried out by Central Java is an attempt to bind the public mind. There are many parties involved in the case of evaluating Central Java. In terms of regional branding, the Central Java Provincial Government collaborates with Mark Plus and the Central Java "Branding" Team consisting of culturalists, academics, marketing experts, and others. Based on this, we can take a straight line that branding in Central Java has been practicing the principles of transparency, participation, and collaboration between elements for branding Central Java.

\section{Hashtag on Twitter account @BanggaKota Surabaya}

The hashtags used by the City of Surabaya on the @BanggaKota Surabaya twitter account consist of \#banggaKota Surabaya, \#lawancovid19, \#Surabayahebat, \#Surabaya city with masks, \#dirumahaja, \#dulursehatsby, \#be used to the unusual, \#arektani, and \#kitaberkota Surabaya. More details can be seen in Figure 12.

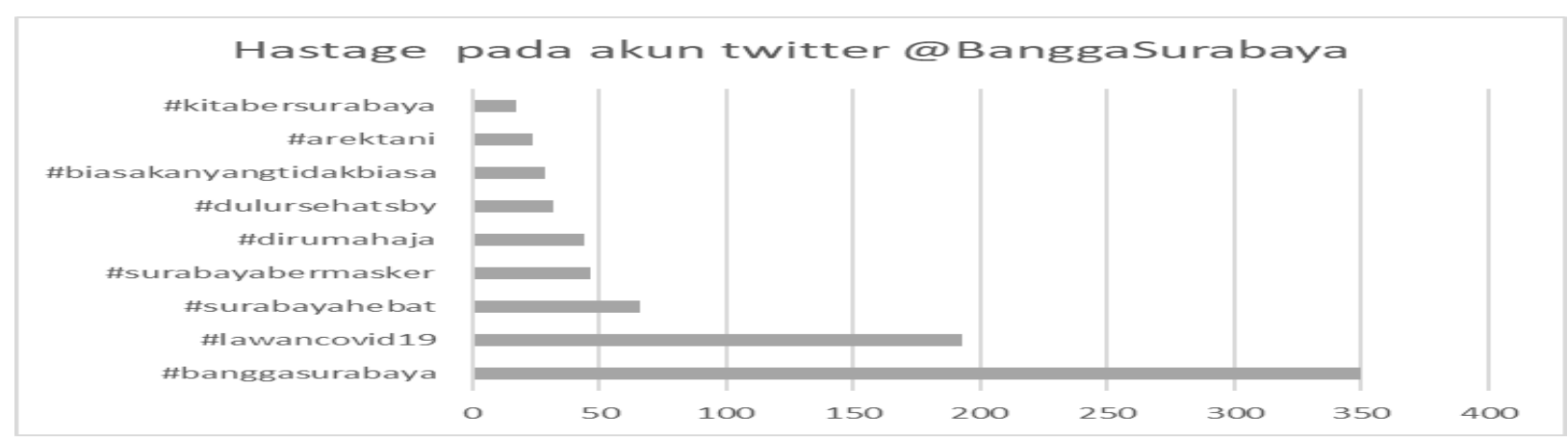

Figure 12: Hashtags that are often used by the @BanggaKota Surabaya account Source: Edited by the author using NVivo 12 Plus, 2021 
Figure 12 shows the hashtags used by the City of Surabaya, with the highest percentage being \#banggaKota Surabaya with the highest score reaching 350 tweets, followed by \#lawancovid19 and \#Kota Surabayahebat. Can analyze that the conversation raised by the @Banggakota Surabaya Twitter account leads to one theme, namely about \#banggakota Surabaya with 350 hashtags on Twitter. If examined further, almost all local governments such as the City of Bandung, DKI Jakarta, and Central Java always use the hashtags \#lawancovid19 and \#at home. Can conclude that in addition to carrying out regional branding, these areas also focus on using health hashtags around Covid-19.

\section{Timeline Tweet Local Government in Indonesia}

The tweet timelines analyzed are the City of Bandung, DKI Jakarta, Central Java, and the City of Surabaya. The period seen is from December 2019 to December 2020. The tweet timeline provides information on how often each local Government uses a Twitter account; the higher the intensity, the more information it can be ascertained. The tweet timeline also provides information regarding the activities of local governments on Twitter within a year.

The following is the comprehensive data from each region's timeline of tweets, including the cities of Bandung and Surabaya and the DKI Jakarta Provincial Government and the Central Java Provincial Government. Figure 13 illustrates this:

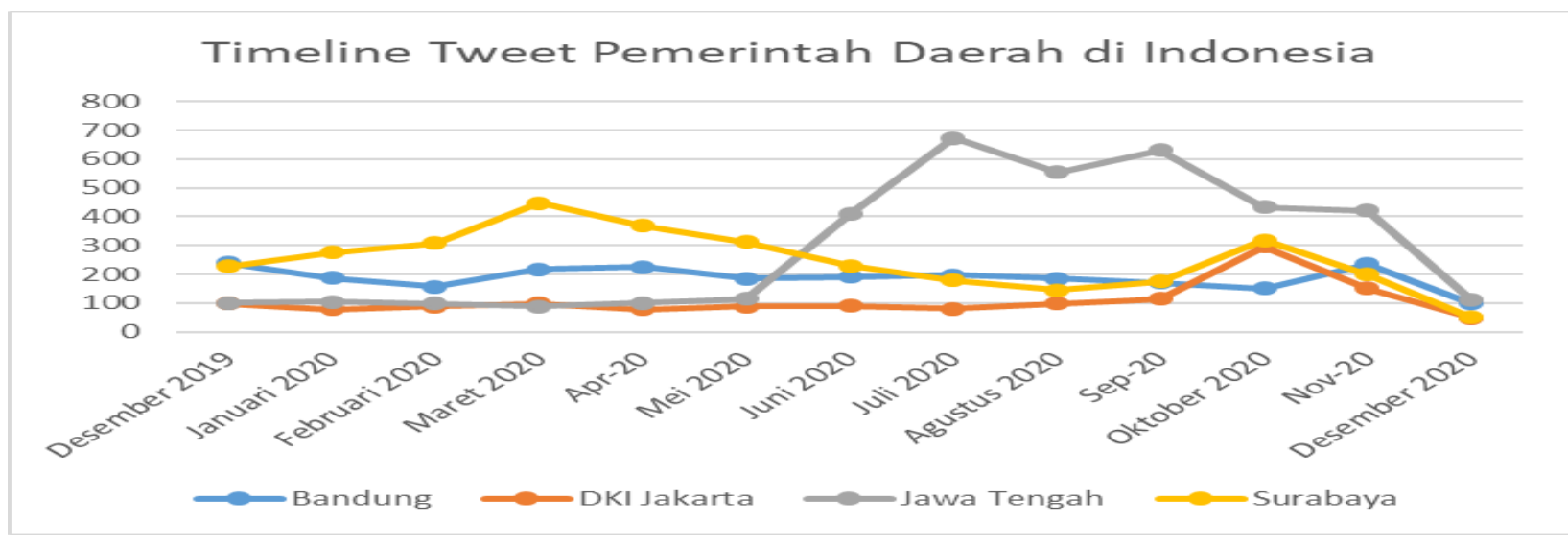

Figure 13: Timeline of Local Government Tweets in Indonesia Source: Edited by the author using NVivo 12 Plus, 2021

Figure 13 presents data on the timeline of local government tweets in Indonesia. The city of Bandung has a fairly regular tweet timeline in the period December 2019 to December 2020. The city of Bandung only has tweets increasing in November 2020 and decreasing in December 2020. DKI Jakarta, when viewed from the data, has a fairly regular tweet timeline; the numbers are from December 2019 to December 2020. DKI Jakarta had a fairly high number in October 2020 and decreased again in December 2020. Central
Java has a tweet timeline that is quite different from other regions, with a higher development starting in May, June to the highest in July 2020. The number of tweets was 700 but then decreased in December 2020. The city of Surabaya has a fairly regular tweet timeline, but the number of increases and decreases is more stable. The month of May 2020 is the highest timeline peak exceeding 400 tweets. Then it will decrease again in December 2020.

\section{Comparison of Local Government Twitter Usage in Indonesia}


A comparative study in the implementing it smart city in Bandung City application of smart cities to the city and Surabaya City, as well as DKI Jakarta government and the provincial Province and Central Java Province, which government. Seeing the difference in area are also different. More clearly can be seen and scope of different administrative in table 1:

authorities, this is one of the reasons for

Table 1: Comparison of Smart City Applications between Cities

\begin{tabular}{|c|c|c|c|}
\hline $\begin{array}{l}\text { Aspect } \\
\text { Comparison }\end{array}$ & Bandung & $\begin{array}{l}\text { Aspect } \\
\text { Comparison }\end{array}$ & Surabaya \\
\hline Application & $\begin{array}{l}\text { Since 2014, the City } \\
\text { Government of } \\
\text { Bandung City has had } \\
394 \text { Smart city } \\
\text { applications. }\end{array}$ & $\begin{array}{l}\text { Government } \\
\text { Internal } \\
\text { Improvement }\end{array}$ & Government system with e-procurement \\
\hline Infrastructure & $\begin{array}{l}\text { Physical and non- } \\
\text { physical development } \\
\text { (digitalization) }\end{array}$ & $\begin{array}{l}\text { Strengthening } \\
\text { Social Capital }\end{array}$ & Belief in values and norms \\
\hline Governance & $\begin{array}{l}\text { Application } \\
\text { management and } \\
\text { utilization in the } \\
\text { smart city era }\end{array}$ & $\begin{array}{l}\text { Government } \\
\text { External Service } \\
\text { Development }\end{array}$ & $\begin{array}{l}\text { e-Government related to the licensing } \\
\text { process, the public can access through the } \\
\text { City of Surabaya Single Window (SSW) }\end{array}$ \\
\hline Data & $\begin{array}{l}\text { Easy, safe and reliable } \\
\text { data } \quad \text { access } \\
\text { transparency. }\end{array}$ & $\begin{array}{l}\text { High-Tech-Based } \\
\text { City Service } \\
\text { Development }\end{array}$ & $\begin{array}{l}\text { High Technology-Based City Services } \\
\text { include Online Mailing, Government } \\
\text { Reporting Systems, Community } \\
\text { Aspirations Communication Media, Online } \\
\text { Licensing Systems, and Urban Information } \\
\text { Media. }\end{array}$ \\
\hline $\begin{array}{l}\text { Human } \\
\text { Resources }\end{array}$ & $\begin{array}{lr}\text { Ability } & \text { to } \\
\text { operationalize and } \\
\text { use (Officer and } \\
\text { Citizen) }\end{array}$ & $\begin{array}{l}\text { Non-Sectoral } \\
\text { Holistic Approach }\end{array}$ & $\begin{array}{l}\text { All factors are taken into account and } \\
\text { depend on each other }\end{array}$ \\
\hline
\end{tabular}

Source: Processed by Author from a different source, 2021

Table 1 explains that each city has a different level of coverage. However, geographically, urban problems tend to be smaller than those in the Provinces. This means that the problems that exist in each city have different strategies to solve problems that arise. More clearly can be seen in table 2.

The smart city concept in Jakarta is described in Table 2. Smart cities must be beneficial to all people for them to have better lives. The smart city concept also allows citizens to participate more actively in data processing, application development, and providing comments and suggestions. A city becomes smart when it can actively involve its residents, Government, and power to attain a better quality of life. Table 3 provides a complete comparison. 
Iman Surya, Niken Nurmiyati, Suranto \& Nur Hasanah, Analysis of The Implementation of Smart

Table 2: Comparison of Smart City Applications between Provinces

\begin{tabular}{|c|c|c|c|}
\hline $\begin{array}{l}\text { Aspect } \\
\text { Comparison }\end{array}$ & DKI Jakarta Province & $\begin{array}{l}\text { Aspect } \\
\text { Comparison }\end{array}$ & Jawa Tengah Province \\
\hline $\begin{array}{l}\text { Smart } \\
\text { Governance }\end{array}$ & $\begin{array}{l}\text { Transparent and open. An example of } \\
\text { an e-Musrenbang application }\end{array}$ & $\begin{array}{l}\text { Smart Social } \\
\text { Services }\end{array}$ & $\begin{array}{l}\text { Smart social services consist of } \\
\text { government, education, health, } \\
\text { security and disaster services. }\end{array}$ \\
\hline Smart Living & $\begin{array}{l}\text { The concept of safety and comfort and } \\
\text { healthy living in Jakarta }\end{array}$ & $\begin{array}{l}\text { Smart } \\
\text { Economy } \\
\text { Service }\end{array}$ & $\begin{array}{l}\text { Smart economy services include } \\
\text { industrial services, forestry, } \\
\text { agriculture, fisheries, tourism, } \\
\text { economic and business centers, } \\
\text { mobility services, etc. }\end{array}$ \\
\hline $\begin{array}{l}\text { Smart } \\
\text { Environment }\end{array}$ & $\begin{array}{l}\text { Eco-friendly and energy-saving } \\
\text { concept }\end{array}$ & $\begin{array}{l}\text { Smart } \\
\text { Environmental } \\
\text { Service }\end{array}$ & $\begin{array}{l}\text { Intelligent environmental services } \\
\text { include energy services, waste } \\
\text { management, water, air, land and } \\
\text { spatial management. }\end{array}$ \\
\hline
\end{tabular}

Source: Processed by Author From Different Source, 2021

Table 3: Comparison of Smart City Implementation between Cities and Provinces

\begin{tabular}{lll}
\hline Komparasi Aspek & Kota & Provinsi \\
\hline & Cakupan secara geografis lebih kecil & Cakupan wilayah lebih luas \\
\cline { 2 - 3 } Smart city & Kewenangan lebih sempit & Kewenangan lebih luas \\
\cline { 2 - 3 } & Cakupan lebih sempit & cakupan lebih luas \\
\cline { 2 - 3 } & Inovasi hanya sebatas fokus di satu kota & $\begin{array}{l}\text { Inovasi bersifat luas dan dapat } \\
\text { diterapkan di beberapa kota }\end{array}$ \\
\cline { 2 - 3 } & Terbatas pada lingkup kota & Luas pada tingkat provinsi \\
\cline { 2 - 3 } & Inovasi menyesuaikan kebutuhan kota & $\begin{array}{l}\text { Inovasi dapat dijadikan percontohan } \\
\text { oleh kota/daerah lain }\end{array}$ \\
\hline
\end{tabular}

Sumber : Diolah Penulis dari berbagai sumber, 2021

The coverage between cities and provinces is significantly different, as seen in Table 3. Aspects of smart Governance, such as the coverage of the city of Bandung vs. the province in DKI Jakarta, are distinct. Indirectly, the breadth of authority makes a difference. Because DKI Jakarta lacks a level II regional government akin to a Regency/City, the difficulties it faces are substantially more complicated. This can be observed in the 14 image comparison.

\section{Smart Governance}

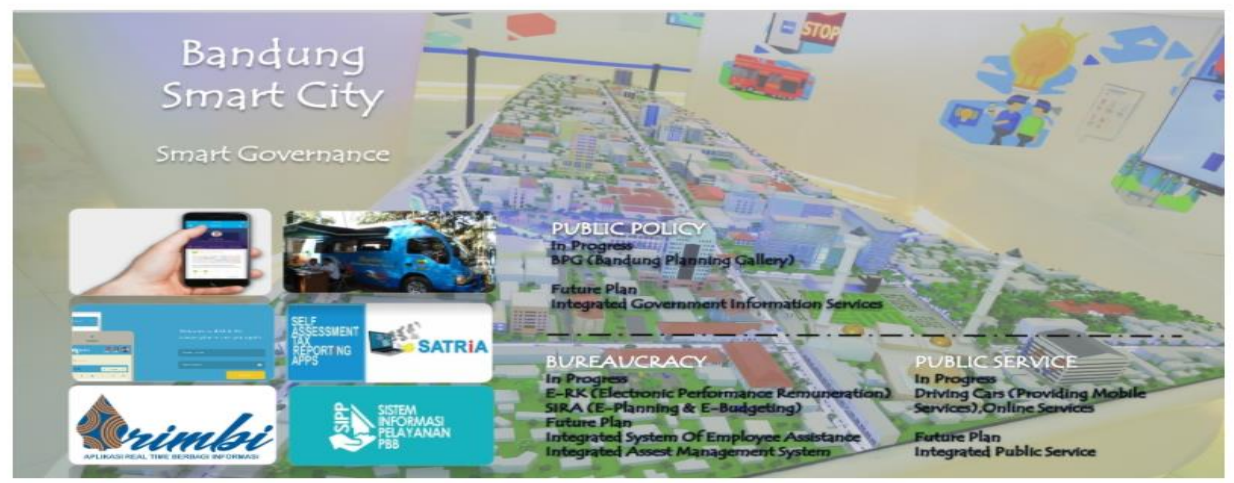

Figure 14: Smart governance Bandung City

Source: https://smartcity Kota Bandung.go.id 
Figure 14 is a display of the city of Bandung smart city to answer and solve city problems. In the smart city era, it's not about competing to increase the number of applications, but how effective the application is for the Community, which is much more important. In the current era of rapid development of information and communication technology, the Government must be more creative, improve the quality of services, one of which is by utilizing technology effectively, efficiently so that it can be effective and efficient following the needs of the Community.

To be effective and efficient, of course, it must look at the situation and conditions of the local community; it is impossible to create applications in remote areas that are not covered by the network. Of course, the various applications created are intended for ready regions, responsive governments, and actively participating communities.

There are several application integrations implemented by the Bandung City Government, which can be seen in Figure 15:
1.0 ICT digitizing experience

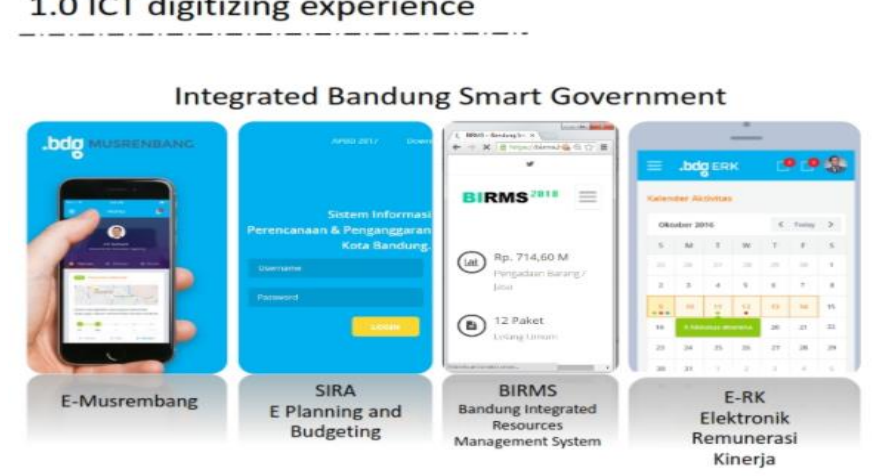

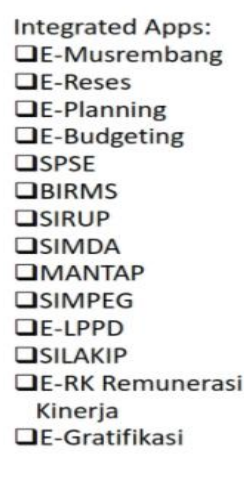

Figure 15: Bandung City Application Integration Source: https://smartcity.Kota Bandung.go.id

Figure 15 can be concluded that the Budgeting, SPSE, BIRMS, SIRUP, SIMDA, integration of smart governance MANTAP, MPEG, E-LPPD, SILAKIP, E- RK applications in Bandung consists of E- Performance Remuneration and EMusrenbang, E-Reses, E-Planning, E- Gratification.

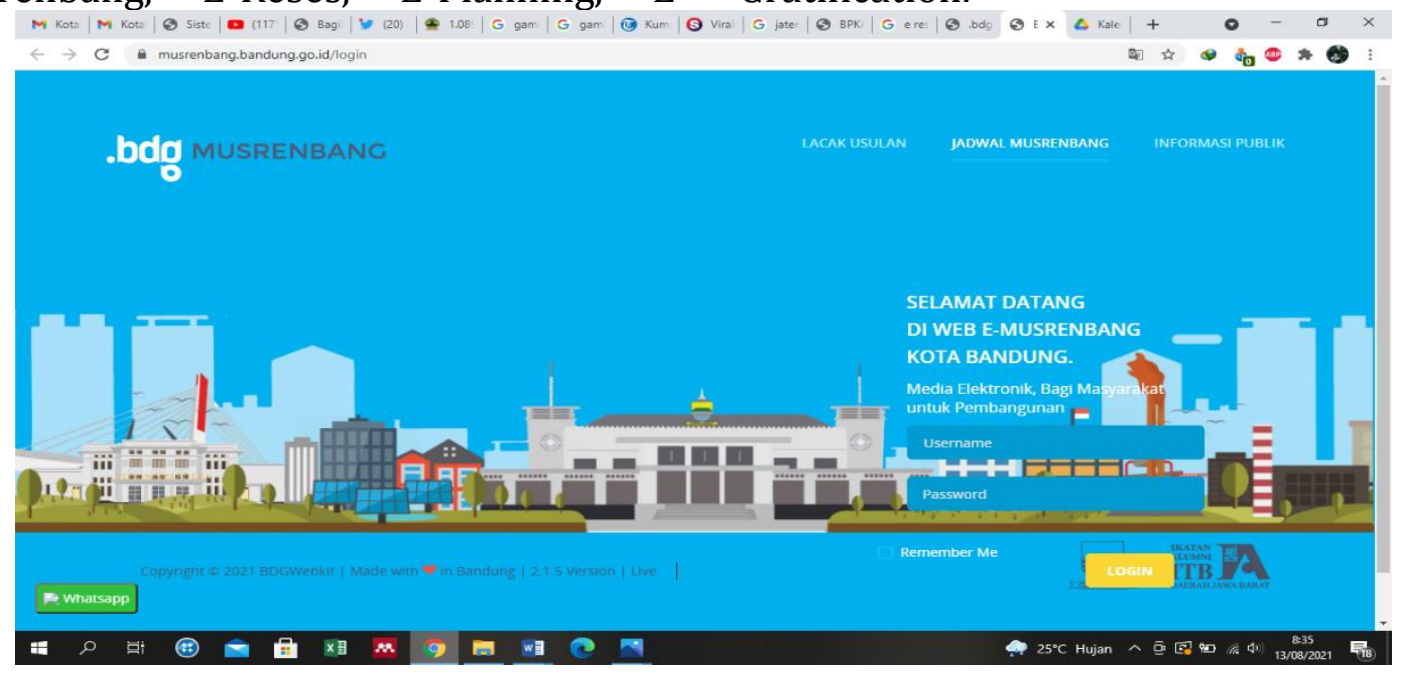

Figure 16: Bandung City Application Integration Source: https://smartcity.Kota Bandung.go.id 
Surabaya, like other cities, has an eGovernment system divided into several parts, such as regional financial management systems, e-HR, e-Monitoring, e-Education, e-Office, Disaster Alert System 112, Online Taxes, e-commerce Permit, eHealth, Simprolamas (public service program information system), e-Dishub, and Media Center.

The data describes the implementation of smart Governance at the city level. The case is different for smart Governance at the provincial level. Smart Governance as one of the important indicators for smart cities requires several important aspects of Governance.

Local governments need to collaborate, involve stakeholders and community participation in overcoming all problems in the public area. Smart Governance claims that in the era of technology that continues to develop, local governments must be more active in collaborating among elements, participating, and continuing to act transparently for the sake of realizing public trust and accountable Government. This can be proven by the transparency of the budget owned by local governments in Indonesia, both containing the APBD or LPJ of each local Government.

\section{CONCLUSION}

The impact of using Twitter on local governments in Indonesia, including the city of Bandung, compares to health and transportation issues. DKI Jakarta deals with health and transportation issues. Central Java deals with health and education issues. The city of Surabaya is competing with health and education issues. For example, Central Java, with the hashtag \#jatenggayeng, successfully branded Central Java so that on Twitter, the hashtags used are very high, and everyone is familiar with the hashtag. This is one way to brand an area to be known by the general public through Twitter. The high level of interaction and hashtag also shows that the public has confidence in the Government as a communicator (Rahmawati, DE; Pratiwi, VP, 2020).

Concerning the implementation of smart Governance and the use of social media in Government, each indicator, such as branding, crisis, participation, and transparency, has been carried out well. Although there are significant differences between cities and provinces, both of them still use Twitter to communicate with the Community.

\section{REFERENCES}

Almeida, V. A. F., Doneda, D., \& Moreira Da Costa, E. (2018). Humane smart cities: The need for governance. IEEE Internet Computing, 22(2), 91-95.

https://doi.org/10.1109/MIC.2018.0220216 71

AlYahmady, H. H., \& Al Abri, S. S. (2013). Using Nvivo for Data Analysis in Qualitative Research. International Interdisciplinary Journal of Education, 2(2), 181-186. https://doi.org/10.12816/0002914

Anggreani, M. D., Purnomo, E. P., \& Kasiwi, A. N. (2020). Ruang Publik Virtual Sebagai Pintu Komunikasi Government To Citizen (Studi Perbandingan Twitter Pemerintah Kota Yogyakarta dan Kota Surabaya). Jurnal MODERAT, 6(1), 203-220. https://jurnal.unigal.ac.id/index.php/moder at/article/view/3165/2919

Bakarbessy, D. (2020). PARTISIPASI MASYARAKAT DALAM IMPLEMENTASI PILOT PROJECT PEMBANGUNAN DESA PARTISIPATIF DI KABUPATEN MALUKU TENGGARA. Ejurnal.Ukim.Ac.Id, 27-35.

Bonson E, Torres L, Royo S, F. F. (2013). LOCAL EGOVERNMENT 2.0: SOCIAL MEDIA AND CORPORATE TRANSPARENCY IN MUNICIPALITIES. Journal of Chemical Information and Modeling, 53(9), 16891699.

https://doi.org/10.1017/CB097811074153 24.004

Castelnovo, W., Misuraca, G., \& Savoldelli, A. (2016). Smart Cities Governance: The Need for a Holistic Approach to Assessing Urban Participatory Policy Making. 
Eom, S. J., Hwang, H., \& Kim, J. H. (2018). Can social media increase government responsiveness? A case study of Seoul, Korea. Government Information Quarterly, 35(1), 109-122. https://doi.org/10.1016/j.giq.2017.10.002

Guillamón, M. D., Ríos, A. M., Gesuele, B., \& Metallo, C. (2016). Factors influencing social media use in local governments: The case of Italy and Spain. Government Information Quarterly, 33(3), 460-471. https://doi.org/10.1016/j.giq.2016.06.005

Lu, B., Zhang, S., \& Fan, W. (2016). Social Representations of Social Media Use in Government: An Analysis of Chinese Government Microblogging From Citizens' Perspective. Social Science Computer Review, 34(4), 416-436. https://doi.org/10.1177/089443931559522 2

Medaglia, R., \& Zhu, D. (2017). Public deliberation on government-managed social media: A study on Weibo users in China. Government Information Quarterly, 34(3), 533-544. https://doi.org/10.1016/j.giq.2017.05.003

Merwin, G. A., McDonald, J. S., Bennett, J. R., \& Merwin, K. A. (2016). Social media applications promote constituent involvement in government management. Strategic Integration of Social Media into Project Management Practice, 272-291. https://doi.org/10.4018/978-1-4666-98673.ch016

Muis, A. R. C. (2020). Transparansi Kebijakan Publik Sebagai Strategi Nasional Dalam Menanggulangi Pandemi Covid-19. SALAM: Jurnal Sosial Dan Budaya Syar-I, 7(5). https://doi.org/10.15408/sjsbs.v7i5.15317
Nurmandi, A., Almarez, D., Roengtam, S., Salahudin, Jovita, H. D., Kusuma Dewi, D. S., \& Efendi, D. (2018). To what extent is social media used in city government policymaking? Case studies in three Asian cities. Public Policy and Administration, 17(4), 600-618. https://doi.org/10.13165/VPA-18-17-4-08

Pereira, G. V., Parycek, P., Falco, E., \& Kleinhans, R. (2018). Smart Governance in the context of smart cities: A literature review. Information Polity, 23(2), 143-162. https://doi.org/10.3233/IP-170067

Rahmawati, DE \& Pratiwi, VP. (2020). Covid-19 Dalam Perspektif Governance. Samudera Biru (LAP IP UMY) : Yogyakarta Hal 190

Ruhlandt, R. W. S. (2018). The Governance of smart cities: A systematic literature review. Cities, 81(October 2017), 1-23. https://doi.org/10.1016/j.cities.2018.02.01 4

https://humas.Kota

Surabaya. go.id/2020/05/09/pemkot-Kota Surabayaajak-umkm-kolaborasi-tangani-covid-19/ (diakses pada 21 Januari 2021)

https://smartcity.Kota Bandung.go.id (diakses pada 21 Januari 2021)

https://samrtcity.jakarta.go.id (Diakses pada 20 January 2021)

https://megapolitan.kompas.com/read/2020/11/ 26/10551091/pemprov-dki-raihpenghargaan-inovasi-pelayanan-publik-darikemenpan-rb (diakses pada 21 January 2021)

http://bappeda.jabarprov.go.id/dokumen/lkpj/ (diakses pada 03 Agustus 2021)

https://bappeko.Kota Surabaya.go.id/informasipublik/kota/itemlist/category/16-lkpj (diakses pada 03 Agustus 2021) 